\title{
Does managerial turnover affect football club share prices?
}

\section{Article}

Published Version

Open Access

Bell, A., Brooks, C. and Markham, T. (2013) Does managerial turnover affect football club share prices? Aestimatio, the IEB International Journal of Finance, 7. 02-21. ISSN 2173-0164 Available at https://centaur.reading.ac.uk/32210/

It is advisable to refer to the publisher's version if you intend to cite from the work. See Guidance on citing.

Publisher: Instituto de Estudios Bursátiles

All outputs in CentAUR are protected by Intellectual Property Rights law, including copyright law. Copyright and IPR is retained by the creators or other copyright holders. Terms and conditions for use of this material are defined in the End User Agreement.

\section{www.reading.ac.uk/centaur}

\section{CentAUR}

Central Archive at the University of Reading

Reading's research outputs online 


\title{
Does Managerial Turnover Affect Football Club Share Prices?
}

\author{
Bell, Adrian R. \\ Brooks, Chris \\ Markham, Tom \\ - received: I3 January 2013 \\ - accepted: II MaRCH 2013
}

\begin{abstract}
This paper analyses the 53 managerial sackings and resignations from 16 stock exchange listed English football clubs during the nine seasons between 2000/01 and $2008 / 09$. The results demonstrate that, on average, a managerial sacking results in a post-announcement day market-adjusted share price rise of $0.3 \%$, whilst a resignation leads to a drop in share price of $1 \%$ that continues for a trading month thereafter, cumulating in a negative abnormal return of over $8 \%$ from a trading day before the event. These findings are intuitive, and suggest that sacking a poorly performing manager may be welcomed by the markets as a possible route to better future match performance, while losing a capable manager through resignation, who typically progresses to a superior job, will result in a drop in a club's share price. The paper also reveals that while the impact of managerial departures on stock price volatilities is less clear-cut, speculation in the newspapers is rife in the build-up to such an event.
\end{abstract}

\section{Keywords:}

Football, Stock returns, Volatility, Management change, Event study.

JEL classification:

M51, L83, G14. 


\title{
¿La gestión del volumen de negocios afecta a la cotización bursátil de los clubs de fútbol?
}

\author{
Bell, Adrian R. \\ Brooks, Chris \\ Markham, Tom
}

\section{Resumen}

Este artículo analiza las 53 destituciones y dimisiones de directivos que han tenido lugar en los 16 clubs de fútbol ingleses que cotizan en bolsa durante las temporadas 2000/01 a 2008/09. Los resultados obtenidos demuestran que el día después del anuncio de una destitución tiene lugar, en promedio, un incremento del $0,3 \%$ en el precio ajustado de la acción, mientras que una dimisión se traduce en una caída del $1 \%$ que se prolonga durante un mes, dando lugar a un rendimiento acumulado negativo anormal cifrado en más del $8 \%$ respecto de la sesión precedente al día del anuncio de la dimisión. Estos resultados son intuitivos, y sugieren que la destitución de un directivo con bajo rendimiento para el club puede ser bienvenida por los mercados, a modo de una posible solución para mejorar los resultados obtenidos en futuros partidos, mientras que la pérdida de un directivo capacitado vía dimisión, que por lo general progresa a una posición superior, resultará en una caída en el precio de las acciones del club. El artículo también pone de manifiesto que, mientras que el impacto de las salidas de directivos en la volatilidad del precio de las acciones no está tan claro, la especulación en la prensa es un factor muy común en la preparación de tal evento.

\section{Palabras clave:}

futbol, Rendimiento de las acciones, Volatilidad, Cambio directivo, Caso de estudio. 


\section{Introduction}

Association football ${ }^{1}$ is big business. It receives unparalleled coverage in print, television and online media. This is clearly evident from the global viewing figures for the English Premier League (EPL), which alone amounted to 4.7 billion people for the 2010/11 season (Harris, 2011). In the same season, the 92 professional English football clubs generated combined revenue of $£ 2.9$ billion (Jones et al., 2011). Many football clubs chose to float on the stock exchange as a means to raise capital since the inception of the EPL in 1992, which saw vast amounts of revenue flood into the game on the back of satellite broadcasting. As is the case for large corporations in appointing a chief executive officer (CEO), hiring the right manager is fundamental to a football club's on-field success and thus continuity and succession planning is key (Borokhovicha, 1996 and Brady et al., 2008). Despite, this, between 1992 and 2005 , the average spell of a club manager within the top four tiers of English football was only 2.19 years (Bridgewater, 2009). ${ }^{2}$

Tottenham Hotspur became the first football club to float on the London Stock Exchange (LSE) in 1983. The club formed a holding company to avoid breaching the Football Association's (FA) Rule 34 which forbade club directors from taking cash out of clubs in the form of salaries or dividends. It was 1989 before another club, Millwall, listed on the stock exchange. In 1991, Manchester United plc was formed and floated on the LSE, coinciding with the formation of the breakaway FA Premier League which commenced the following August. The satellite television rights for this new league were controversially sold to BSkyB for $£ 305 m$ over five seasons (Conn, 2005). With significant media revenues guaranteed for a sustained period, along with the future prospect of pay per view matches, football was seen as an attractive investment. Consequently, a large number of football clubs listed on stock exchanges to raise finance to be spent on infrastructure and the development of on-field success.

With managerial departures so prevalent within the game, an event study is undertaken in the present paper to ascertain whether the sacking or resignation of a manager influences a football club's share price. We also examine the prevalence of media speculation around such departures, and investigate whether it is related to returns. An abundance of empirical research exists examining the effect that managerial turnover has on the share price (and ultimate valuation) of mainstream companies, yet there is virtually nothing on the football industry specifically. Fotaki et al. (2009) represents the closest research to that in the present study. However,

\footnotetext{
I Association football is commonly referred to as 'soccer' in the USA in order to distinguish the game from American football. Throughout the paper we use the term 'football' rather than 'soccer'.

${ }^{2}$ Bell et al. (2013) present a model to evaluate football manager performance and they find several managers in their sample who appeared to have been sacked prematurely regarding the on-field results they achieved.
} 
their paper focuses the effects that the human resource policies of UK listed clubs in their entirety have on a club's share price. They examine player transfers, player loans and managerial turnover between 1997 and 2004 using a Resource-Based View (RBV), which is used in human resource management research to explain how employee performance adds value to corporations. Their study on the UK football industry concludes that the sacking of managers, the sale of players and the return of players from a loan have positive effects on stock returns. However, they also specifically point out that to date, no literature exists examining the effect of managerial turnover in isolation on a club's share price, and they state that their research does not differentiate between involuntary and voluntary coach turnover, the precise subject under consideration in the present paper. As we demonstrate below, the manner of departure of a manager has important implications for the club's share price reaction and thus it is important to separate voluntary and involuntary departures.

The remainder of this paper is structured as follows. Section 2 examines literature relevant to this study on both the factors affecting football club share prices and an entirely separate area concerning the impact of managerial departures on the share prices of companies. Section 3 outlines the data and methodology used in the research while Section 4 presents the results. Finally, Section 5 concludes with the paper's findings and highlights some suggestions for further research.

\section{Previous Literature}

There have been a number of studies examining the reasons behind the movements in football club share prices. Football clubs are in quite a unique position in that many factors which could potentially influence their share prices occur at the weekend when the financial markets are closed. This means that the information from such events will feed into a club's share price when the market re-opens on Monday. Unsurprisingly, the predominant focus of many studies in this area centres on match results. Bell et al. (2012) employ an event study approach and consider the significance of fixtures by assessing whether opposing sides are competing for the same league position (particularly in the case of clubs chasing promotion or fighting relegation). Their research finds that match results do have a small impact on club share prices but that this is overshadowed by other variables.

A similar study is undertaken by Scholtens and Peenstra (2009), where 1,274 domestic and European games of eight teams were analysed between 2000 and 2004. They show that the markets respond positively to victories and negatively to defeats. The results are stronger for European games compared to domestic competitions. A comparable finding is established by Renneboog and Vanbrabant (2000) in their 
study of how match results affect UK listed football clubs. The results show a gain of $1 \%$ on average following a win, a fall of $0.6 \%$ for a draw and a drop of $1.4 \%$ for a loss, on club share values. Corresponding results are attained in Portugal according to Alexandre and Ferreira (2005). Benkraiem et al. (2011) produce extremely similar results in their study of English games in the 2006/07 season, but also add that defeats at home produce the largest drop in a club's share price. Their paper stresses the importance of intangible assets (players) in the sector and the difficulty in attributing a fair value to them. Palomino et al. (2009) find that abnormal returns on the back of team victories are in not in line with rational expectations but can instead be attributed to overreactions by investors following the result.

The causes of movements in the share price of Germany's only listed club, Borussia Dortmund, are reviewed by Stadtmann (2006), who finds that results do influence the club's value in the same manner outlined previously along with corporate governance-related variables. Ashton et al. (2003) show that sport results do have an influence on the stock exchange when analysing changes to the FTSE 100 following England international football matches, although this was contradicted in a study by Boyle and Walter (2003). Yet this viewpoint is not shared in the conclusive evidence put forward by the event study employed Edmans et al. (2007). The primary supported sports (football, rugby, cricket, basketball and ice hockey) in every country with a developed financial market (47 countries worldwide) are used and the results for football show that a monthly equivalent fall of $7 \%$ was the average outcome for an international football loss. Smaller losses also emerge following a national team's loss in international cricket, rugby, and basketball games in countries where these sports are prevalent. The results elucidate that the larger the competition, the greater the impact, particularly in the case of losses. There is no support for the premise that an improved market performance would follow on the back of wins.

As we have noted, there are a number of factors, including loss of a manager, that can influence a football club's share price. Examples of such factors could include player transfers and contract renewals (Fotaki et al., 2009; Hickman et al., 2008), media deals, sponsorship deals (Spais and Filis, 2008), a new stadium, a proposed take-over of a club, football governance regulation changes (for example, see the seminal legal cases relating to Bosman and Webster), the announcement of the company's earnings, general movements of the stock market, and ex-dividend dates (Bell et al., 2012). But does the loss of the equivalent of a manager, for instance, a CEO in a regular company, have the same impact on its share price? We now review some of the key studies on this topic.

Early research by Warner et al. (1988) states that there is a negative relationship between management changes and a company's share performance. Relatedly, Denis 
and Denis (1995) find that the sacking of a CEO is preceded by a significant drop in share value and followed by large rise following the appointment of a successor, a finding echoed by Franks et al. (2001). Bonnier and Bruner (1989) and Huson et al. (2004) agree with this viewpoint and state that management change due to substandard performance will lead to gains for shareholders following the dismissal.

The seminal papers referred to above are based on US data, while Conyon and Flourou (2002) is a UK study that reviews the firing of top executives for unsatisfactory performance between 1990 and 1998 at 460 companies. Their results show that shares rise on average by $3 \%$ following a sacking. Another study by Mahajan and Lummer (1993) adds to this by stating that a shift in top level management has an adverse effect on a company's share price. French research on the subject by Dherment-Ferere and Renneboog (2002) breaks down a number of reasons behind a CEO's departure: dismissal, voluntary departures and age-related retirements. Sackings lead to a positive abnormal return of $0.5 \%$ in a company's share price. Voluntary resignations do not result in share price changes whilst age-related turnover causes a small negative price reaction.

Dedman and Lin (2002) find companies that opt not to announce CEO departures have inferior performance records and a higher chance of future failure than firms who officially announce CEO turnover to the LSE. The authors further reveal that a company's share price falls when a CEO leaves voluntarily to take up another post. This is also a prominent feature of the football industry where high performing managers often resign to move to higher profile positions. George Burley quitting as the Southampton manager, then listed on the Alternative Investment Market (AIM), in 2008 to take over as manager of the Scottish national team is an example of this (Nathanson, 2008). Khorana (2001) looks at the replacement of fund managers (often compared to football managers in the sense that they also have large assets under their control) and how it influences fund values. The sample period between 1979 and 1991 examines 393 fund managers who were replaced. When an underperforming manager is replaced, it results in improved performance whilst when an over-performing manager quits, cash is withdrawn from the fund by clients and performance subsequently drops. Similar results are found by Gallagher (2003) and Gallagher and Nadarajah (2004) pertaining to the Australian fund management market.

Billger and Hallock (2005) examine the relationship between staff layoff announcements and CEO turnover over a 31-year period. The authors find that layoffs significantly increase the likelihood of a CEO leaving the company in the following two years. This is also prevalent in the football sector where many managers, particularly of smaller clubs, tend to leave their posts once a star player has been sold. Martin O'Neill's departure from Aston Villa following the sale of James Milner to 
Manchester City prior to the start of the Premier League's 2010/11 season is one such example (Davies, 2010). The research shows that layoffs are consequently associated with negative stock price returns.

Another important factor for football clubs is the expectation regarding performance. Puffer and Weintrop (1991) claim that a company's board sets its corporate performance and it is up to a CEO to deliver this level of performance. Financial analysts' forecasts are substituted for board expectation and a sample of 408 US listed companies is examined for CEO dismissals to substantiate these findings. This perspective is shown again by Farrell and Whidbee (2003), who suggest that company boards focus on divergence from expected performance, rather than performance alone, in making CEO dismissal decisions.

On the basis of the evidence examined in the literature discussed above, it appears likely that managerial turnover could affect a football club's share price in the same manner as it does for a regular company, and we now investigate this issue in detail.

\section{Data and Methodology}

Clubs listed on the stock exchanges possess similar organisational structures to those of regular companies enabling comparability (Fotaki et al., 2009 and Wright et al., 1995). Following several studies discussed above, we employ an event study methodology to assess the impact managerial turnover as it is the most appropriate approach to investigate the impact on returns, volatilities and trading volumes of an announcement which is easy to date accurately and where the relevant sample can be identified in an obvious way.

The 53 managerial departures between the 2000/01 and 2008/09 seasons inclusive are provided by League Managers Association (LMA). Club share price data are compiled from Datastream. In all cases, the closing share price was used. The FTSE All Share Index is employed in the calculation of the market adjusted returns to remove any independent market movements that may have influenced club share prices on a given day. ${ }^{3}$ The All Share Index was selected over other indices as it is comprised of companies of all sizes and sectors. The historical FTSE All Share Index data are obtained from Datastream. The status of clubs and their listings is amended from Bell et al. (2012).

\footnotetext{
${ }^{3}$ We did not use the market model but instead calculated abnormal returns by simply subtracting the benchmark return away from the actual company return. Given that we only examine a short time window, this implicit assumption that the stock beta is one should not be consequential, and ensures that we do not have any estimation issues to be concerned with.
} 
Managerial departures are divided into three categories: sackings, resignations and caretakers (short-term). Of the 53 managerial departures: 30 were sackings, 17 were resignations and six were caretaker roles. Due to the short-term nature of caretaker spells and their small number, they are disregarded for the calculation of our results. We examine raw share price returns and market-adjusted returns, as well as both of these constructed on a cumulative basis, although we only report the market-adjusted returns in Table 1 and the results are qualitatively identical whether raw or marketadjusted returns are considered.

Table 1. Football Club's Average Daily Percentage Returns and Volumes around Managerial departure

\begin{tabular}{|c|c|c|c|c|c|c|}
\hline Departure dat & Club & Manager(s) & $\begin{array}{c}\text { Av. T-20 } \\
\text { to TO }\end{array}$ & $\mathrm{T}+1$ & $\begin{array}{l}\text { Av. } T+2 \\
\text { to } T+20\end{array}$ & $\begin{array}{c}\text { Volume } \\
\text { Ratio }\end{array}$ \\
\hline \multicolumn{7}{|c|}{ Panel A: Sackings } \\
\hline 12-Sep-00 & Chelsea & Gianluca Vialli & -0.14 & -1.56 & -0.03 & 0.49 \\
\hline 17-Sep-00 & Millwall & Alan McLeary/Keith Stevens & -0.48 & 0.23 & 0.30 & 0.07 \\
\hline 30-Sep-01 & Leicester City & Peter Taylor & -0.51 & -0.50 & -1.14 & 0.26 \\
\hline 15-Oct-01 & Birmingham City & Trevor Francis & -1.47 & 24.32 & -0.50 & 1.14 \\
\hline 14-Jun-02 & Watford & Gianluca Vialli & 0.56 & -2.41 & 0.61 & 15.47 \\
\hline 27-Jun-02 & Leeds United & David O'Leary & -0.04 & -2.30 & 2.35 & 3.62 \\
\hline 07-Oct-02 & Sunderland & Peter Reid & 0.11 & -2.17 & -0.81 & 5.21 \\
\hline 10-Mar-03 & Sunderland & Howard Wilkinson & -0.80 & -0.22 & -2.02 & 5.80 \\
\hline 21-Mar-03 & Leeds United & Terry Venables & -1.53 & -6.38 & 0.65 & 2.69 \\
\hline $15-0 c t-03$ & Millwall & Mark McGhee & -0.60 & 0.59 & -0.03 & 0.50 \\
\hline 10-Nov-03 & Leeds United & Peter Reid & -0.31 & 7.99 & 4.04 & 6.71 \\
\hline 29-Aug-04 & Preston North End & Craig Brown & 0.00 & 0.09 & -0.05 & - \\
\hline 30-Aug-04 & Newcastle United & Bobby Robson & -0.42 & -0.70 & -0.01 & 0.96 \\
\hline $26-0 c t-04$ & West Bromwich Albion & Gary Megson & -0.05 & -0.95 & -0.06 & - \\
\hline 22-Mar-05 & Watford & Ray Lewington & 0.10 & 0.70 & 0.06 & 0.15 \\
\hline 27-Jul-05 & Millwall & Steve Claridge & -0.01 & 0.35 & -0.89 & 0.16 \\
\hline 21-Dec-05 & Millwall & Colin Lee & 2.07 & -0.25 & -0.07 & 0.21 \\
\hline 02-Feb-06 & Newcastle United & Graeme Souness & 0.05 & -0.18 & -0.30 & 0.26 \\
\hline 02-Jun-06 & Preston North End & Billy Davies & -0.54 & 0.18 & -0.16 & 0.33 \\
\hline 25-Sep-06 & Millwall & Nigel Spackman & -0.93 & -1.21 & -1.59 & 3.06 \\
\hline 06-May-07 & Newcastle United & Glenn Roeder & 0.70 & 0.79 & 1.52 & - \\
\hline 14-May-07 & Manchester City & Stuart Pearce & -1.63 & -2.00 & -3.11 & 0.96 \\
\hline 08-Oct-07 & Millwall & Willie Donachie & -0.24 & -1.08 & 0.11 & 1.39 \\
\hline 25-Oct-07 & Tottenham & Martin Jol & 0.67 & -1.12 & 0.49 & 0.43 \\
\hline 13-Nov-07 & Preston North End & Paul Simpson & 0.12 & -2.16 & -0.14 & 0.45 \\
\hline 14-Feb-08 & Sheffield United & Bryan Robson & -0.12 & 1.60 & 0.53 & 2.34 \\
\hline 28-May-08 & Southampton & Nigel Pearson & 0.12 & -0.02 & 0.37 & 0.14 \\
\hline $25-0 c t-08$ & Tottenham & Juande Ramos & -0.24 & 1.62 & 0.17 & 3.24 \\
\hline 03-Nov-08 & Watford & Aidy Boothroyd & 0.37 & -1.64 & 0.20 & 0.13 \\
\hline 23-Jan-09 & Southampton & Jan Poortvliet & 0.74 & -2.11 & 0.10 & 1.90 \\
\hline \multicolumn{3}{|c|}{ Sackings Average } & -0.15 & 0.32 & 0.02 & 2.15 \\
\hline
\end{tabular}




\begin{tabular}{lcccccr}
\hline Departure date & Club & Manager(s) & $\begin{array}{c}\text { Av. T-20 } \\
\text { to T0 }\end{array}$ & T+1 & $\begin{array}{c}\text { Av. T+2 } \\
\text { to T+20 }\end{array}$ & $\begin{array}{r}\text { Volume } \\
\text { Ratio }\end{array}$ \\
\hline Panel B: Sackings & & & & & \\
\hline 25-Feb-01 & Queens Park Rangers & Gerry Francis & 0.90 & 0.34 & -2.82 & 2.37 \\
\hline 24-Jan-02 & Aston Villa & John Gregory & -0.07 & 0.73 & 0.16 & 2.84 \\
\hline 15-Mar-02 & Preston North End & David Moyes & -1.23 & -0.18 & -0.50 & 0.01 \\
\hline 06-Apr-02 & Leicester City & Dave Bassett & -1.24 & 0.99 & -0.03 & 23.32 \\
\hline 20-Nov-02 & Sunderland & Ricky Sbragia & 0.00 & -2.17 & 0.15 & 3.35 \\
\hline 14-May-03 & Aston Villa & Graham Taylor & 0.11 & -3.00 & 0.22 & 0.64 \\
\hline 13-Feb-04 & Southampton & Gordon Strachan & 0.44 & -3.48 & 0.06 & 1.35 \\
\hline 23-Jun-04 & Southampton & Paul Sturrock & -0.55 & -8.83 & -0.29 & 1.31 \\
\hline 05-Nov-04 & Tottenham & Jacques Santini & 0.03 & -1.74 & -0.03 & 1.82 \\
\hline 10-Mar-05 & Manchester City & Kevin Keegan & 0.42 & -1.73 & 0.10 & 4.21 \\
\hline 08-May-05 & Millwall & Dennis Wise & -0.61 & 0.13 & -0.15 & - \\
\hline 03-Dec-05 & Southampton & Harry Redknapp & -0.33 & 0.30 & 0.26 & 2.94 \\
\hline 08-May-06 & Charlton Athletic & Alan Curbishley & 0.20 & -0.53 & 0.41 & 1.66 \\
\hline 16-May-07 & Sheffield United & Neil Warnock & -0.54 & 1.59 & 0.30 & 0.49 \\
\hline 19-Nov-07 & Birmingham City & Steve Bruce & -0.32 & -2.81 & -0.46 & 0.30 \\
\hline 23-Jan-08 & Southampton & George Burley & 0.65 & 0.20 & 0.17 & 1.91 \\
\hline 05-Jun-09 & Watford & Brendan Rogers & -1.29 & 3.70 & 0.20 & 0.04 \\
\hline Resignations & Average & & -0.20 & -0.97 & -0.13 & 3.04 \\
\hline
\end{tabular}

The volatilities of each club's share price are calculated as annualised standard deviations over the 20-day periods before and after the announcements. We also compute variance ratios as the maximum of the pre-announcement variance over the post-announcement variance or the post-announcement variance over the preannouncement variance. We can then test the null hypothesis that the variance ratios are unity; under the null, the ratios follow an F-distribution with $(19,19)$ degrees of freedom.

CEOs of the largest corporations frequently receive a profusion of media coverage. This paper seeks to determine whether the impact is comparable to managerial turnover in the football industry where media coverage is even more intensive. In order to achieve this, we obtain media data from UK national newspapers: the Daily Mail, the Daily Star, the Daily Telegraph, the Express, the Guardian, the Independent, the Independent on Sunday, the Mail on Sunday, the Mirror, the Sunday Mirror, the Observer, the People, the Sun, the Sunday Express, the Sunday Telegraph, the Sunday Times and the Times, from the Lexis Nexis database. We counted the number of stories that comprised of the departing manager's name along with the following key words: 'sack', 'sacks', 'sacked', 'fire', 'fires', 'fired', 'dismiss', 'dismisses', 'dismissed', 'terminate', 'terminates', 'terminated', 'let go', 'boot', 'axe', 'axes', 'axed', 'chop', 'laid off, 'shown door', 'marching orders', 'elbow', 'vote of confidence', 'mutual consent', 'resign', 'leave', 'depart' and 'stand down', which we then split into departures designated as sackings and those designated as resignations. This search was designed to cater for both 
tabloids and broadsheets for the sample period under review from 2000/01 to 2008/09. Following a thorough review to ensure that all stories were relevant to managerial departures, we were left with 1,418 stories pertaining to the 47 dismissals and resignations during the period.

\section{Results}

This section examines the percentage change in football clubs' share prices for the 20 days the market is open pre- and post-managerial departure, and the results for sackings are presented in Panel A of Table 1 and for resignations in Panel B for all of the individual managers and, in the final row, as an unweighted average across all departures. For pre-announcement returns it is clear that there are relatively more negative returns (18) versus positive returns (12) in the run up to sackings as opposed to resignations ( 9 negative, 8 positive). Day " 0 " is the day that the departure is announced, although this sometimes happens over the weekend or out of trading hours, and therefore we focus primarily on day " $T+1$ ", which is the day after the announcement. The most significant findings relate to the first trading day after a manager has left his post. This is often on a Monday after a manager has been dismissed following a "last straw" unsatisfactory weekend result. In the case of managerial sackings, club share prices rise on average by a market-adjusted $0.32 \%$ following modest falls the trading month prior to the announcement. This suggests that the market approves of the clubs' decisions to dismiss their managers and hence the share prices increased accordingly. This is particularly evident (from Table 1) in the cases of Trevor Francis with Birmingham City in 2001/02 and Peter Reid being fired at Leeds United in 2008/09 with share prices rising by an adjusted $24.32 \%$ and 7.99\% respectively. ${ }^{4}$ In the case of Terry Venables' dismissal due to poor on-field performance at Leeds United in 2003/04, the club's share price fell by an adjusted $6.38 \%$, but this market reaction is confounded by the club's financial plight and market expectations of an inability to replace him with an equally skilled candidate. A club's capability and strategic planning is imperative in the sacking process as clubs tend to already have their next manager lined up before formally announcing and conducting the dismissal, thus minimising the impact of the shock from a share price perspective.

Conversely, this is often not possible in the case of resignations, which may come as a surprise to clubs and be out of their control. In the case of the resignations, club

\footnotetext{
${ }^{4}$ We should note, however, that the positive on-announcement returns for sackings is driven largely by the response of Birmingham City's share price to the sacking of Trevor Francis. Without this observation, both on-event day effects are negative, but the impact of resignations is still more negative and thus our key result that resignations have a worse impact on share prices than sackings is still maintained.
} 
share prices fall on average by $0.97 \%$ on the first trading day after the event (see Panel B of Table 1). This advocates that the market objects to the uncertainty of losing a manager unexpectedly. The majority of resignations relate to a successful manager moving to a higher profile position at another club or national association, and the share price falls reflect the difficulty in replacing departing candidates with managers of an equal or superior ability level. This is particularly evident in the cases of Gordon Strachan and Paul Sturrock, who both resigned as manager of Southampton during the 04/05 season, resulting in market-adjusted share price falls of $3.48 \%$ and $8.83 \%$ the day afterwards.

During the trading month (i.e. 20 trading days) following the departure, the share prices of clubs sacking their managers continue to be mixed, with around $53 \%$ of prices falling, but no overall trends; the average market-adjusted return after sackings is a slightly positive $0.7 \%$ from day $T+1$ to $T+20$ inclusive. By contrast, the reaction to resignations continues to be negative for $(T+1, T+20)$, with an average price fall of $3.44 \%$. Overall, we can also conclude that, despite the small size and illiquidity of football club stocks, most of the share price reaction to sackings (positive) and resignations (negative) occurs on the very first day of the announcement.

The final column of Table 1 also reports the volume ratios for each departure, which are calculated as the average daily trading volume for the 20 trading days after departure divided by the average daily trading volume before departure. Thus, a figure less than one indicates that volumes fell while a figure greater indicates that they rose. We are not able to report the ratios for several clubs where there was insufficient trading activity to be able present reliable figures. While outliers may have influenced the volume ratios for specific departures (for example, if there was a large block transaction during the event period), if we focus upon the number of volume ratios that are bigger than or less than one, the findings are very clear. In cases where the manager was sacked, trading volumes rose in 11 cases but fell in 15; for resignations, however, volumes rose in 11 cases but fell in only five. While we cannot identify whether the originators of the increased trades were predominantly buyers or sellers, this result ties in with that for returns whereby resignations are considered differently by the markets, with resignations having a considerably bigger impact upon trading volumes than sackings - trading volumes (on average) double in the trading month after a sacking compared with the month before, but they triple for resignations.

In order to more easily visualise the impact of sackings compared with resignations, Figure 1 plots the cumulative returns starting from day T-20 and summing them thereafter. It is clear that share prices fall slightly on average during the trading 
month before a manager is sacked, but they actually rise slightly prior to a resignation until about three days before the event. By this time, there is probably considerable leakage of the impending managerial turnover, with the result that the share price has already started to fall. By date $T+1$, on average sacking club share prices have fallen a cumulative 3\% approximately, while they have fallen by almost $6 \%$ for resignations. Thereafter, share prices for the sackings sample start to recover, so that by $T+20$ they have clawed back almost all of their losses, while the resignations sample stocks continue their fall to end the trading month after the event some $8 \%$ below the values they traded at a month before it.

\section{Figure 1. Average cumulative market-adjusted returns around managerial}

\section{departures}

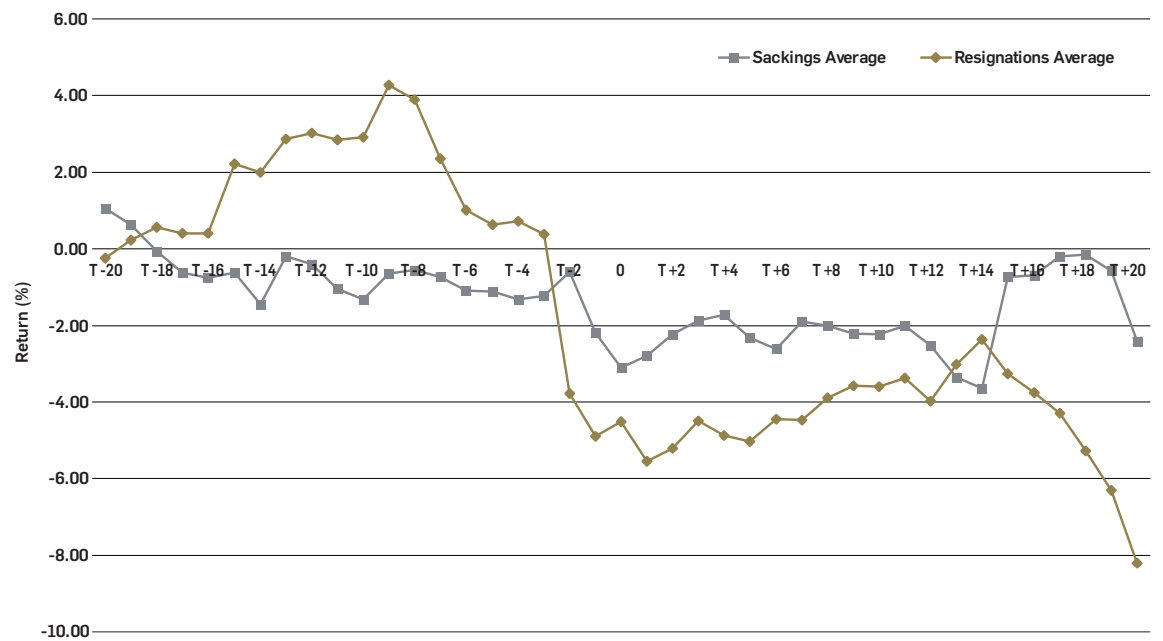

This figure presents the cumulative abnormal returns from 20 days before sackings (square symbols) and resignations (diamonds) for all stock-market listed English football clubs from 2000/0I to 2008/09.

Investors usually focus on risk-adjusted returns and as such, we examine whether the share price volatilities were higher or lower following managerial departures and therefore, de facto, whether the shares became more or less risky. Table 2 thus repeats the analysis of Table 1 for sackings and resignations (respectively in Panels $A$ and $B$ ), but this time focusing on volatilities (which are annualised) rather than returns. It is clear that while football club shares are thinly traded, when the prices move, they can rise or fall by a considerable amount in a short space of time. Some of the stocks are extremely volatile - for example, Leeds United stock's volatility was 95\% the month before Peter Reid was sacked and 235\% the month thereafter; these figures are several times higher than would be typical of most other stocks. 
Table 2. Annualised Football Club Share Price Return Volatility Around Managerial Departure

\begin{tabular}{|c|c|c|c|c|c|c|}
\hline Departure date & Club & Manager(s) & $\begin{array}{c}\text { Av. T-20 } \\
\text { to } T 1\end{array}$ & $\begin{array}{l}\text { Av. T0 } \\
\text { to } T+20\end{array}$ & $\begin{array}{c}\text { Variance } \\
\text { Ratio }\end{array}$ & $\mathrm{p}$-value \\
\hline \multicolumn{7}{|c|}{ Panel A: Sackings } \\
\hline 12-Sep-00 & Chelsea & GianlucaVialli & $44.91 \%$ & $16.46 \%$ & 7.44 & 0.00 \\
\hline 17-Sep-00 & Millwall & lan McLeary/Keith Stevens & $41.27 \%$ & $67.77 \%$ & 2.70 & 0.02 \\
\hline 30-Sep-01 & Leicester City & Peter Taylor & $64.10 \%$ & $31.26 \%$ & 4.21 & 0.00 \\
\hline 15-Oct-01 & Birmingham City & Trevor Francis & $37.99 \%$ & $103.50 \%$ & 7.42 & 0.00 \\
\hline 14-Jun-02 & Watford & GianlucaVialli & $0.00 \%$ & $0.00 \%$ & $\mathrm{n} / \mathrm{a}$ & $\mathrm{n} / \mathrm{a}$ \\
\hline 27-Jun-02 & Leeds United & David O'Leary & $13.92 \%$ & $72.04 \%$ & 26.78 & 0.00 \\
\hline 07-Oct-02 & Sunderland & Peter Reid & $16.40 \%$ & $27.48 \%$ & 2.81 & 0.01 \\
\hline 10-Mar-03 & Sunderland & Howard Wilkinson & $37.97 \%$ & $74.94 \%$ & 3.90 & 0.00 \\
\hline 21-Mar-03 & Leeds United & Terry Venables & $42.74 \%$ & $108.60 \%$ & 6.46 & 0.00 \\
\hline 15-Oct-03 & Millwall & Mark McGhee & $70.75 \%$ & $0.00 \%$ & $\mathrm{n} / \mathrm{a}$ & $\mathrm{n} / \mathrm{a}$ \\
\hline 10-Nov-03 & Leeds United & Peter Reid & $95.26 \%$ & $234.65 \%$ & 6.07 & 0.00 \\
\hline 29-Aug-04 & Preston North End & Craig Brown & $5.73 \%$ & $0.00 \%$ & $\mathrm{n} / \mathrm{a}$ & $\mathrm{n} / \mathrm{a}$ \\
\hline 30-Aug-04 & Newcastle United & Bobby Robson & $21.00 \%$ & $33.01 \%$ & 2.47 & 0.03 \\
\hline 26-Oct-04 V & West Bromwich Albion & Gary Megson & $0.00 \%$ & $5.18 \%$ & $\mathrm{n} / \mathrm{a}$ & $\mathrm{n} / \mathrm{a}$ \\
\hline 22-Mar-05 & Watford & Ray Lewington & $0.00 \%$ & $0.00 \%$ & $\mathrm{n} / \mathrm{a}$ & $\mathrm{n} / \mathrm{a}$ \\
\hline 27-Jul-05 & Millwall & Steve Claridge & $97.26 \%$ & $54.72 \%$ & 3.16 & 0.01 \\
\hline 21-Dec-05 & Millwall & Colin Lee & $168.68 \%$ & $0.00 \%$ & $\mathrm{n} / \mathrm{a}$ & $\mathrm{n} / \mathrm{a}$ \\
\hline 02-Feb-06 & Newcastle United & Graeme Souness & $7.67 \%$ & $11.72 \%$ & 2.34 & 0.04 \\
\hline 02-Jun-06 & Preston North End & Billy Davies & $62.57 \%$ & $3.13 \%$ & 400.23 & 0.00 \\
\hline 25-Sep-06 & Millwall & Nigel Spackman & $79.21 \%$ & $102.12 \%$ & 1.66 & 0.14 \\
\hline 06-May-07 & Newcastle United & Glenn Roeder & $31.86 \%$ & $50.23 \%$ & 2.49 & 0.03 \\
\hline 14-May-07 & Manchester City & Stuart Pearce & $27.83 \%$ & $68.56 \%$ & 6.07 & 0.00 \\
\hline 08-Oct-07 & Millwall & Willie Donachie & $0.00 \%$ & $0.00 \%$ & $\mathrm{n} / \mathrm{a}$ & $\mathrm{n} / \mathrm{a}$ \\
\hline 25-Oct-07 & Tottenham Hotspur & Martin Jol & $32.75 \%$ & $22.53 \%$ & 2.11 & 0.06 \\
\hline 13-Nov-07 & Preston North End & Paul Simpson & $4.27 \%$ & $7.08 \%$ & 2.75 & 0.02 \\
\hline 14-Feb-08 & Sheffield United & Bryan Robson & $14.49 \%$ & $23.81 \%$ & 2.70 & 0.02 \\
\hline 28-May-08 & Southampton & Nigel Pearson & $46.94 \%$ & $8.24 \%$ & 32.44 & 0.00 \\
\hline 25-Oct-08 & Tottenham Hotspur & Juande Ramos & $93.70 \%$ & $53.80 \%$ & 3.03 & 0.01 \\
\hline 03-Nov-08 & Watford & AidyBoothroyd & $232.23 \%$ & $141.00 \%$ & 2.71 & 0.02 \\
\hline 23-Jan-09 & Southampton & Jan Poortvliet & $39.06 \%$ & $31.95 \%$ & 1.49 & 0.19 \\
\hline \multicolumn{3}{|c|}{ Sackings Average } & $47.68 \%$ & $45.13 \%$ & & \\
\hline
\end{tabular}

\begin{tabular}{lcccccc}
\hline Panel B: Sackings & & & & & \\
\hline 25-Feb-01 & Queens Park Rangers & Gerry Francis & $47.40 \%$ & $125.06 \%$ & 6.96 & 0.00 \\
\hline 24-Jan-02 & Aston Villa & John Gregory & $6.56 \%$ & $8.03 \%$ & 1.50 & 0.19 \\
\hline $15-M a r-02$ & Preston North End & David Moyes & $64.22 \%$ & $34.49 \%$ & 3.47 & 0.00 \\
\hline O6-Apr-02 & Leicester City & Dave Bassett & $92.12 \%$ & $0.00 \%$ & 0.00 & 1.00 \\
\hline 20-Nov-02 & Sunderland & Ricky Sbragia & $0.00 \%$ & $14.32 \%$ & $\mathrm{n} / \mathrm{a}$ & $\mathrm{n} / \mathrm{a}$ \\
\hline 14-May-03 & Aston Villa & Graham Taylor & $4.76 \%$ & $13.60 \%$ & 8.16 & 0.00 \\
\hline 13-Feb-04 & Southampton & Gordon Strachan & $31.85 \%$ & $20.02 \%$ & 2.53 & 0.02 \\
\hline 23-Jun-04 & Southampton & Paul Sturrock & $20.78 \%$ & $51.39 \%$ & 6.12 & 0.00
\end{tabular}




\begin{tabular}{lcccccc} 
05-Nov-04 & Tottenham Hotspur & Jacques Santini & $13.71 \%$ & $19.71 \%$ & 2.07 & 0.06 \\
\hline 10-Mar-05 & Manchester City & Kevin Keegan & $18.81 \%$ & $16.27 \%$ & 1.34 & 0.27 \\
\hline 08-May-05 & Millwall & Dennis Wise & $54.72 \%$ & $0.00 \%$ & n/a & n/a \\
\hline O3-Dec-05 & Southampton & Harry Redknapp & $7.29 \%$ & $17.04 \%$ & 5.46 & 0.00 \\
\hline 08-May-06 & Charlton Athletic & Alan Curbishley & $4.90 \%$ & $6.82 \%$ & 1.94 & 0.08 \\
\hline 16-May-07 & Sheffield United & Neil Warnock & $118.94 \%$ & $29.39 \%$ & 16.38 & 0.00 \\
\hline 19-Nov-07 & Birmingham City & Steve Bruce & $42.67 \%$ & $48.95 \%$ & 1.32 & 0.28 \\
\hline 23-Jan-08 & Southampton & George Burley & $18.19 \%$ & $66.29 \%$ & 13.28 & 0.00 \\
\hline 05-Jun-09 & Watford & Brendan Rogers & $160.23 \%$ & $154.72 \%$ & 1.07 & 0.44 \\
\hline Resignations Average & & $\mathbf{4 1 . 6 0 \%}$ & $\mathbf{3 6 . 8 3} \%$ & & \\
\hline
\end{tabular}

Notes:The volatilities are measured as annualised standard deviations over the I-month period before and after the announcement. The variance ratios are calculated as max(pre/post, post/pre), where pre and post are the variances of returns before and after the event. The $p$-values in the final column test the null hypothesis that the variance ratios are unity; under the null the ratios follow an $F$ distribution with $(19,19)$ degrees of freedom.

Unlike the fairly strong results for the returns-based analysis, those for the volatilities are ambiguous. Overall, volatilities fall slightly on average for both sackings and resignations, although they are higher for the former sample than the latter. Sackings often take place in an environment where a club has a range of problems, off-thefield as well as on it, and this may impact upon the share price return volatilities both before and after the sackings. Some of the larger changes in volatilities at the individual club level are for Leeds United, whose share price volatility rose from $14 \%$ to $72 \%$ following the sacking of David O'Leary in June 2002 and Southampton, whose share price volatility fell from $47 \%$ to $8 \%$ following the sacking of Nigel Pearson in May 2008. Similarly, for the resignations sample, the departure of Neil Warnock from Sheffield United in May 2007 stands out as volatility fell from 119\% before the resignation to $29 \%$ after; on the other hand volatility rose from $18 \%$ to $66 \%$ following the departure of George Burley from Southampton in January 2008.

Considering the variance ratios reported in the penultimate column and their associated $p$-values in the final column of Panel $A$ in Table 2, among the 20 clubs where the return variances changed significantly (using a 5\% significance level), 13 (i.e. two thirds) significantly rose while only one third significantly fell. For the resignations in Panel $B$ of Table 2, there were eight clubs whose return variances changed significantly, and five (again around two thirds) significantly rose and a third significantly fell. So we can conclude on this point by saying that although it is not the case for all clubs, in the main both resignations and departures increase the volatility and therefore the riskiness of share prices for most individual football clubs, although the average volatilities fall in both cases.

As the most popular sport in the United Kingdom, football receives an enormous amount of media coverage. Speculation regarding the game is endemic, particularly in newspapers. With this in mind, we now examine whether media speculation regarding managerial departures impacts the share price of listed clubs. To this end, 
Figure 2 illustrates the average number of stories per manager for each of the twenty trading days prior to the departure. We do not examine days after the event since the information has then become public knowledge and the number of newspaper stories reporting it is therefore irrelevant. We can see that the number of stories is roughly constant at around two per manager until three days before the departure for both sackings and resignations, but then it increases considerably to over five (almost three) the day before departure for resignations (sackings).

\section{Figure 2. National newspaper reports prior to managerial departures.}

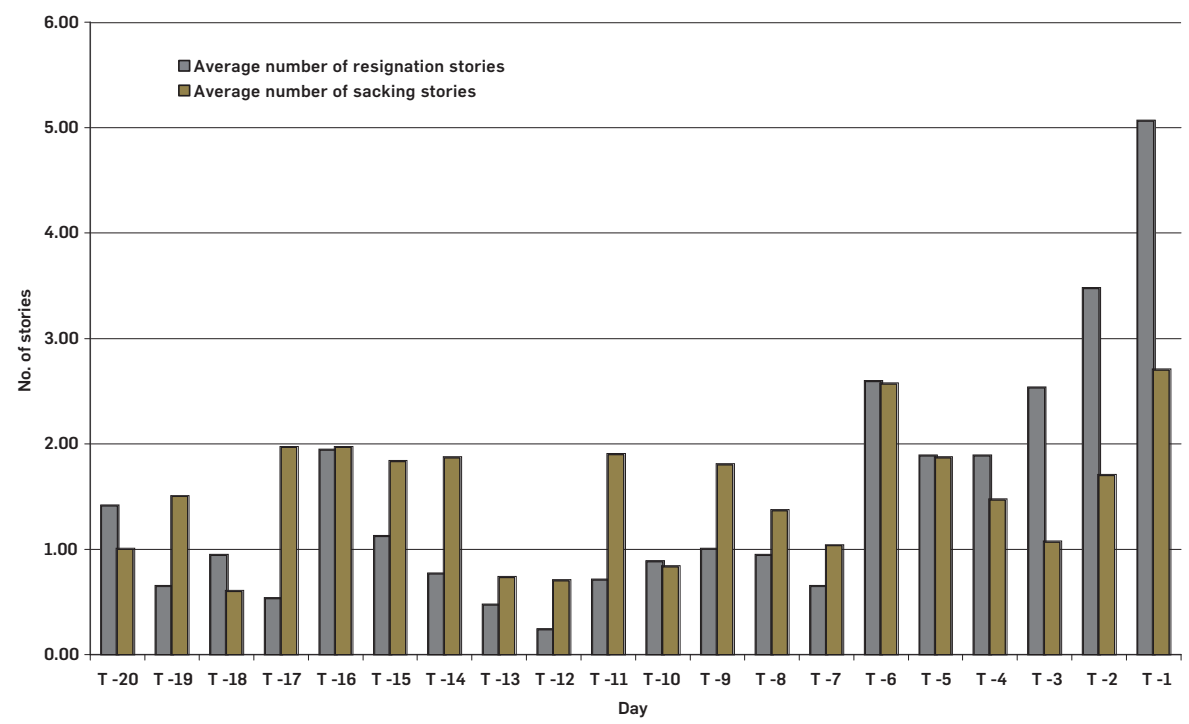

Note:This figure reports the average number of stories relating to the club manager per day during the 20 days before a resignation or a sacking from I 7 English newspapers for all stock-market listed English football clubs over the seasons 2000/0I to 2008/09.

A comparison of the numbers in Figure 2 with those in Table 1 and Figure 1 reveals that that on average if there are more than two stories relating to a potential managerial departure there is a fall of at least $0.5 \%$ in a club's share price. Combining sackings and resignations, there is an average of 2.57 newspaper stories published six days before a manager lost his job resulting in a drop in marketadjusted share value of $0.68 \%$. This increases to an average market-adjusted fall of $1.02 \%$ two days before the manager actually departs. The average market-adjusted drop in a club's share value almost doubles to $1.40 \%$ the market day before a manager leaves his post with average of 3.55 news features on his departure. Media interest is at its highest during the last two days before a departure and for the resignations in particular, this is the time at which the returns are at their most extreme (and negative). Although we do not investigate the share price movements in situations where there is considerable media speculation regarding a possible departure that does not materialise (or does not materialise for some time 
afterwards), ${ }^{5}$ our results suggest that that an investor may be able to pursue a profitable investment strategy in football club shares through the compilation and analysis of media speculation pertaining to managerial departures, especially by short selling the stocks of companies where there is considerable reporting of imminent resignations.

\section{Conclusions}

This paper analyses the 53 managerial sackings and resignations from 16 stock exchange listed English football clubs during the nine seasons between 2000/01 and 2008/09. The unique aspect of this research is that it distinguishes between "involuntary" and "voluntary" managerial turnover. Our approach is more nuanced, which is important since football managers are entitled to large compensation packages, the size of which are ultimately decided by the manner of their exit. Thus a sacking could have a much bigger impact on the club in financial terms. From the research conducted, it can be concluded that managerial departures do result in discernible changes in football club share prices. The average stock price (and ultimate value) of football clubs is more sensitive to managerial resignations, with considerably greater falls, compared with sackings. These findings are intuitive, whereby a poorly performing manager will be sacked leading to higher expectations regarding future on-field performance from shareholders and a consequent rise in share price. The opposite can be said about losing a capable manager through resignation (typically progressing to superior job) which will result in a drop in a club's share price. These findings correlate with the analogous literature concerning mainstream corporate managerial turnover as is notably illustrated by Denis and Denis (1995), Conyon and Flourou (2002) and Huson et al. (2004), but are not consistent with market efficiency given that the adjustment is continuing to take place a whole trading month after the original announcement, although this may in part reflect the lack of liquidity of football company shares.

In conclusion, football club managerial turnover is comparable to CEO departures in regular stock exchange listed corporations. There are a at least two directions that the research in this study could be taken in the future. First, an automated approach to examining media reports concerning possible managerial departures could be conducted to determine whether such attention could be used to predict the actual timings of the departures. A second issue not addressed in the present paper relates to the divisional status of clubs and whether those in higher divisions are more affected by managerial departures than those in lower divisions, due to it being harder to find available managers of the appropriate stature and experience.

\footnotetext{
${ }^{5}$ Given that our examination of the media reports is conducted manually, this would be an infeasible task.
} 


\section{Acknowledgements}

We thank David Matthews for assistance with data collection and two anonymous referees for their useful comments on an earlier version of this paper.

\section{References}

Alexandre, N. and Ferreira, A. (2005). Explaining share price performance of football clubs listed on the Euronext Lisbon, ISEG - Universidade Tecnica de Lisboa Business Administration Working Paper No. 05-01. Available from: <http://papers.ssrn.com/sol3/papers.cfm?abstract_id=675633> [Accessed: 19 November 2012].

- Ashton, J., Gerrard, B. and Hudson, R. (2003). Economic impact of national sporting success: evidence from the London stock exchange, Applied Economics Letters, 10, pp. 783-785.

- Bell, A., Brooks, C., Matthews, D. and Sutcliffe, C. (2012). Over the Moon or Sick as a Parrot? The Effects of Football Results on a Club's Share Price, Applied Economics, 44(26), pp. 3435-3452.

Bell, A.R., Brooks, C., and Markham, T. (2013). The Performance of Football Club Managers: Skill or Luck?, Economics and Finance Research, 1, pp. 19-30.

Benkraiem, R., Le Roy, F. and Louhichi, W. (2011). Sporting Performances and the Volatility of Listed English Football Clubs, International Journal of Sport Finance, 6, pp. 283-297.

Billger, S. and Hallock, K. (2005). Mass Layoffs and CEO Turnover, Industrial Relations, 44(3), pp. 463-489.

Bonnier, K. and Bruner, R. (1989). An Analysis of Stock Price Reaction to Management Change in Distressed Firms, Journal of Accounting and Economics, 11, pp. 95 - 106.

- Borokhovicha, K.A., Parrinoa, R. and Trapani, T. (1996). Outside Directors and CEO Selection, Journal of Financial and Quantitative Analysis, 31(3), pp. 337-355.

Boyle, G. and Walter, B. (2003). Reflected glory and failure: international sporting success and the stock market, Applied Financial Economics, 13, pp. 225-235.

- Brady, C., Bolchover, D. and Sturgess, B. (2008). Managing in the Talent Economy: The Football Model for Business, California Management Review, 50(4), pp. 54-73.

Bridgewater, S. (2009). What is the Impact of Changing Football Manager? University of Warwick Business School Working Paper. Available from: <http://www.wbs.ac.uk/downloads/news/2009/ 10/what-is-the-impact-of-changing-football-manag.pdf> [Accessed: 19 November 2012].

Conn, D. (2005). Rattled Premier League executives sense revolt in the air, The Guardian, 5 October 2005. Available from: <http://www.guardian.co.uk/football/2005/oct/05/newsstory.sport8> [Accessed: 20 November 2012]. 
Conyon, M. and Florou, A. (2002). Top executive dismissal, ownership and corporate performance, Accounting \& Business Research, 32(4), pp.209-261.

Davies, T. (2010). Martin O'Neill resigns as Aston Villa manager, The Guardian, 9 August 2010. Available from: <http://www.guardian.co.uk/football/2010/aug/09/martin-oneill-resigns aston-villa> [Accessed: 20 November 2012].

Dherment-Ferere, I. and Renneboog, L. (2002). Share Price Reactions to CEO Resignations and Large Shareholder Monitoring in Listed French Companies, in Convergence and diversity of corporate governance regimes and capital markets (eds. McCahery, J. et al.), Oxford University Press, Oxford, pp. 297-324.

Dedman, E. and Lin, S. (2002). Shareholder Wealth Effects of CEO Departures: Evidence from the UK, Journal of Corporate Finance, 8(1), pp. 81-104.

Denis, D.J. and Denis, D.K. (1995). Changes Following Top Management Dismissals, Journal of Finance, 50(4), pp. 1029-1057.

Edmans, A., García, D. and Norli, Ø (2007). Sports Sentiment and Stock Returns, Journal of Finance, 62(4), pp. 1967-1998.

Farrell, K. and Whidbee, D. (2003). Impact of firm performance expectations on CEO turnover and replacement decisions, Journal of Accounting and Economics, 36, pp. 165-196.

Fotaki, M., Markellos, R.N. and Mania, M. (2009). Human Resources Turnover as an Asset Acquisition, Accumulation and Divestiture Process, Working paper, Athens University of Economics and Business. Available from: <http://web.econ.ku.dk/fru/Events_News/PDF/HR\%20Turnover\%20revision.pdf> [Accessed: 22 November 2012].

Franks, J., Mayer, C., \& Renneboog, L.D.R. (2001). Who disciplines the management of poorly performing companies?, Journal of Financial Intermediation, 10(3/4), pp. 209-248.

Gallagher, D. (2003). Investment manager characteristics, strategy, top management changes and fund performance, Accounting and Finance, 43, pp.283-309.

Gallagher, D. and Nadarajah, P. (2004). Top Management Turnover: An Analysis of Active Australian Investment Managers, Australian Journal of Management, 29, pp. 243-274.

- Harris, N. (2011). A football competition and a headline about a global audience of billions. And yet it's actually true. What on earth is going on? Sportingintelligence.com, 27th October.

Hickman. K., Cooper, S. and Agyei-Ampomah, S. (2008). Estimating the value of victory: English football, Applied Financial Economics Letters, 4, pp. 299-302.

Huson, M., Malatesta, P. and Parrino, R. (2004). Managerial succession and firm performance, Journal of Financial Economics, 74(2), pp. 237-275.

Jones, D., Rawnsley, P. and Switzer, A. (2011). Annual Review of Football Finance 20th Edition, Deloitte Sports Business Group.

Khorana, A. (2001). Performance Changes following Top Management Turnover: Evidence from 
Open-End Mutual Funds, Journal of Financial and Quantitative Analysis, 36(3), pp. 371-393.

Lehn, K.M. and Zhao, M. (2006), CEO Turnover after Acquisitions: Are Bad Bidders Fired?, Journal of Finance, 61, pp. 1759-1811.

Mahajan, A. and Lummer, S. (1993). Shareholder Wealth Effects of Management Changes, Journal of Business Finance \& Accounting, 20(3), pp. 393-410.

- Nathanson, P. (2008). George Burley appointed Scotland manager, Telegraph.co.uk, 24th January. Available from: <http://www.telegraph.co.uk/sport/football/teams/scotland/2289913/George-Burley appointed-Scotland-manager.html> [Accessed: 23 November 2012].

- Palomino, F., Renneboog, L. and Zhang, C. (2009). Information salience, investor sentiment, and stock returns: the case of British soccer betting, Journal of Corporate Finance, 15, pp. 368-387.

Puffer, S. and Weintrop, J. (1991). Corporate performance and CEO turnover: the role of performance expectations, Administrative Science Quarterly, 36, pp. 1-19.

- Renneboog, L. and Vanbrabant, P. (2000). Share Price Reactions to Sporty Performances of Soccer Clubs listed on the London Stock Exchange and the AIM, Tilburg University, Center for Economic Research Paper. Available from: <http://arno.uvt.nl/show.cgi?fid=4038> [Accessed: 23 November 2012].

Scholtens, B. and Peenstra, W. (2009). Scoring on the stock exchange? The effect of football matches on stock market returns: an event study, Applied Economics, 41, pp. 3231-3237.

- Spais, G. and Filis, G. (2008). Measuring stock market reaction to sponsorship announcements: The case of Fiat and Juventus, Journal of Targeting Measurement and Analysis for Marketing, 16(3), pp. 169-180.

- Stadtmann, G. (2006). Frequent News and Pure Signals: The Case of a Publicly Traded Football Club, Scottish Journal of Political Economy, 53(4), pp. 485-504.

Warner, J. Watfs, R. and Wruck, K. Karen (1988). Stock Prices and Top Management Changes, Journal of Financial Economics, 20, pp. 461-492.

Wright, P., Smart, D. and McMaham, G. (1995). Matches between Human Resources and Strategy among NCAA Basketball Teams, Academy of Management Journal, 38(4), pp. 1052-1074. 
